\title{
Peningkatan Kemampuan Siswa Sekolah Menengah Pertama Membaca Puisi dengan Metode Pembelajaran Aktif Kreatif dan Menyenangkan
}

\section{Enhancing the Ability of Junior High School Students Poetry Reading with Active Learning Methods Creative and Fun}

\author{
Muhammad Yakob1)* \& Maida Sari ${ }^{2)}$ \\ 1)Program Studi Bahasa Indonesia, Fakultas Keguruan dan Ilmu Pendidikan \\ Universitas Samudra, Indonesia \\ 2)Program Studi Bahasa Inggris, SMPN 4 Langsa, Indonesia
}

Diterima: Juli 2019; Disetujui: Juli 2019; Dipublish: Agustus 2019

*Coresponding Email: myakob_mhum@unsam.ac.id

\begin{abstract}
Abstrak
Penelitian ini bertujuan untuk meningkatkan kemampuan siswa Sekolah Menengah Pertama membaca puisi dengan metode pembelajaran aktif, kreatif dan menyenangkan. Penelitian ini merupakan penelitian tindakan kelas. Subjek penelitian adalah siswa kelas VIII semester genap Sekolah Menengah Pertama Negeri 13 Langsa yang berjumlah 29 Siswa. Objek dalam penelitian ini adalah penerapan metode pembelajaran aktif, kreatif dan menyenangkan. Alat dalam pengumpulan data adalah pengamatan, observasi, dan penugasan dengan jalur siklus, yaitu siklus I dan siklus II. Hal ini ditunjukkan. Hasil nilai rata-rata pada siklus pertama 53,6 dengan ketuntasan 24,13\%. Pada siklus berikutnya (kedua) terjadi peningkatan 78,9 dengan ketuntasan 86,2\%. Dengan peningkatan aktivitas belajar siswa pada siklus-siklus tindakan yang dilakukan. Dengan demikian, hasil pada siklus II dapat dikatakan telah memenuhi nilai ketuntasan. Penerapan metode pembelajaran aktif, kreatif dan menyenangkan dalam meningkatkan keterampilan siswa membaca puisi pada Sekolah Menengah Pertama Negeri 13 Langsa. Dari hasil penelitian dapat disimpulkan bahwa Penerapan metode pembelajaran aktif, kreatif dan menyenangkan dapat meningkatkan hasil belajar siswa dalam pembelajaran membaca puisi.
\end{abstract}

Kata Kunci: Metode Pembelajaran, Aktif, Kreatif dan Menyenangkan, Membaca Puisi

\begin{abstract}
This study aims to improve the ability of junior high school students to read poetry with active, creative and fun learning methods. This research is a classroom action research. The research subjects were the eighth grade students in the even semester of the 13 Langsa State High School, totaling 29 students. The object in this study is the application of active, creative and fun learning methods. Tools in collecting data are observation, observation, and assignment with cycle paths, namely cycle I and cycle II. This is indicated. The average score in the first cycle was 53.6 with completeness of $24.13 \%$. In the next (second) cycle there was an increase of 78.9 with completeness of $86.2 \%$. By increasing student learning activities in the cycles of actions taken. Thus, the results in cycle II can be said to have fulfilled the value of completeness. Application of active, creative and fun learning methods in improving students' skills in reading poetry at Langsa 13 Junior High School. From the results of the study it can be concluded that the application of active, creative and fun learning methods can improve student learning outcomes in learning to read poetry.
\end{abstract}

Keywords: Learning Methods, Active, Creative And Fun, Reading Poetry

How to Cite: Yakob. M \& Sari. M. (2019). Peningkatan kemampuan Siswa SMP Membaca Puisi Dengan Metode Pembelajaran Aktif Kreatif dan Menyenangkan. Journal of Education, Humaniora and Social Sciences (JEHSS). 2 (1):93 - 103 


\section{PENDAHULUAN}

Guru bahasa dan sastra Indonesia harus dapat memahami pada performansi berbahasa daripada sekedar memiliki pengetahuan tentang kebahasaan, yakni berupa terampil dalam mengeksplor diri mempergunakan bahasa dalam konteks tertentu sesuai dengan fungsi komunikatif bahasa. Pembelajaran sastra sangat terkait dengan materi dan metode serta serta keterampilan yang digunakan oleh pendidik. Metode pembelajaran yang sesuai akan menimbulkan suasana belajar sastra yang apresiatif kepada siswa. Metode sangat berperan di dalam pembelajaran yang akan menghasilkan kegiatan belajar yang menyenangkan, efektif dan efisien. Dengan demikian, pembelajaran sastra itu sendiri tidak bersifat monoton, melainkan lebih bersifat variatif. Di samping itu, peran guru juga sangat penting dalam memahami berbagai variasi metode pembelajaran. Seperti diungkap (Situmorang, 1983) "guru merupakan titik sentral peningkatan kualitas pendidikan." Dengan memahami berbagai metode, seorang guru akan menyajikan pembelajaran secara aktif, kreatif dan menyenangkan di dalam penyajian pembelajaran yang berhasil.

Guru bahasa dan sastra Indonesia harus dapat memahami dan memiliki pengetahuan tentang kebahasaan maupun kesussastraan yakni berupa terampil dalam mengeksplor diri siswa untuk dapat mempergunakan bahasa dalam memahami materi membaca puisi konteks tertentu sesuai dengan fungsi komunikatif berbahasa. Guru harus mampu dapat memotivasi siswa sesuai dengan perkembangan zaman seiring dengan pengaruh perubahan global. Pemilihan suatu metode pembelajaran harus ditempuh oleh guru dalam rangka memberikan sebuah pemahaman pada siswa tentang materi pelajaran yang meraka pelajari. Metode sangat berpengaruh besar dalam suatu pembelajaran dengan pemilihan metode yang sesuai nilai siswa dapat meningkat. Hasil penelitian menunjukkan bahwa prestasi belajar siswa dengan menggunakan metode pembelajaran, aktif, kreatif dan menyenangkan lebih tinggi dibandingkan dengan menggunakan metode konvensional. Siswa lebih aktif dalam mengikuti pembelajaran dan peningkatan nilai yang mencapai nilai ketuntasan.

Keterampilan membaca merupakan salah satu aspek keterampilan berbahasa sesuai dengan tuntutan kurikulum k-13 mata pelajaran bahasa Indonesia. Di antara sejumlah materi pembelajaran keterampilan membaca pada kelas VIII SMP adalah membaca puisi. Pembalajaran membaca puisi bertujuan agar siswa mampu membaca 94 
puisi dengan lafal, intonasi, mimik, dan penghayatan yang tepat, (Depdiknas, 2005). Keterampilan siswa dalam membaca puisi tidak akan tercapai tanpa dibina melalui proses pembelajaran oleh guru yang terampil, metode yang tepat, siswa yang memiliki motivasi, dan pelatihan yang efektif.

Puisi merupakan bentuk penyampaian gagasan yang bersifat emosional mengandung penghayatan dan penjiwaan. Puisi dapat mengekspresikan perasaan dan merangsang imajinasi dengan susunan bahasa yang berirama. Untuk membacanya memerlukan penghayatan sehingga pengungkapan emosi sebagai hasil pencitraan objek oleh penyair dapat diekspresikan oleh pembaca (Pertiwi, 2017). Dalam hal ini, apabila pembelajaran tentang materi membaca puisi tidak dibina dan dilatih terutama dalam bentuk penjiwaan maka hasil pembelajaran membaca puisi tidak akan maksimal.

Pembacaan puisi yang baik harus melalui proses pembelajaran yang efektif. Siswa memiliki pengetahuan tentang membaca puisi dan terampil membacanya. Hal tersebut sesuai dengan tuntutan Kurikulum K-13 dijelaskan oleh (Depdiknas, 2013) adalah "Tujuan pembelajaran membaca puisi untuk mengembang kepribadian meningkatkan keterampilan bahasa dan keterampilan mengungkapkan perasaan emosi yang diperlihatkan melalui penggunaan lafal, intonasi, mimik dan gerak tubuh saat membacanya.

Apabila siswa belum terampil membaca puisi dapat dikatakan tujuan pembelajaran membaca puisi belum tuntas. Untuk mendapatkan siswa yang terampil membaca puisi diperlukan pelatihan dari guru, kemauan, dan ketekunan siswa dalam kegiatan pembelajaran dan latihan secara individual dan secara berkolaborasi. Pembelajaran membaca puisi termasuk materi yang sukar diajarkan oleh guru sehingga minat siswa untuk belajar membaca yang sesuai dengan tuntutan menjadi rendah. Materi pembelajaran yang sukar dapat teratasi dengan cara memilih metode pembelajaran yang tepat dan hasilnya proses yang meningkat.

Pembelajaran membaca puisi selama ini dilaksanakan dengan pembelajaran langsung, artinya guru menyuruh siswa membaca puisi dalam hati selanjutnya diminta kepada siswa secara individual membaca puisi di depan temannya. Pada akhir pembelajaran guru tidak menanggapi tentang apakah pembacaan puisi oleh siswa sudah baik atau belum. Guru dengan asumsinya memberikan nilai pembacaan puisi kepada 
setiap siswa. Akhirnya, terkesan pembelajaran membaca puisi kaku dan tidak dapat meningkatkan hasil pembelajarannya.

Metode Pakem adalah metode pembelajaran aktif, kreatif, efektif dan menyenangkan. Pembelajaran keterampilan bahasa dengan metode pakem baru dalam 2010 dipopulerkan melalui pelatihan guru. Suparlan, dkk (2008) mengatakan bahwa: Sejarah PAKEM pertama kali munculnya dikenal dengan istilah Pakem, semula dikembangkan dari AJEL (Active Joyful and Effective Learning). Untuk pertama kali di Indonesia yaitu pada tahun 1999 yang dikenal dengan istilah PEAM (Pembelajaran Efektif, Aktif dan Menyenangkan), (Syah,2009) mengatakan bahwa: PAKEM atau singkatan dari Pembelajaran Aktif, Kreatif, Efektif dan Menyenangkan merupakan suatu metode pembelajaran yang dirancang agar mengaktifkan anak, mengembangkan kreatifitas, sehingga efektif namun tetap menyenangkan.

Tujuannya agar mutu dan hasil pembelajaran dapat meningkat. Pembelajaran dengan metode Pakem sesuai dengan tuntutan pembelajaran Kurikulum K-13 pada mata pelajaran bahasa Indonesia (Depdiknas, 2016). Pada guru memprediksikan metode pakem untuk pembelajaran membaca termasuk membaca puisi lebih tepat. Tepat tidaknya metode tersebut akan terbukti pada hasil proses pembelajarannya tuntas dan dapat digunakan oleh guru.

Pembelajaran membaca puisi yang dilaksanakan dengan metode Pakem dilaksanakan secara terencana dan sistematis. Proses tersebut dapat dilihat pada penyusunan program, pelaksanaan pembelajaran, penilaian hasil pembelajaran, dan hasil pembelajarannya. Sebagian kecil guru telah dilatih melaksanakan pembelajaran dengan metode pakem, karena itu perlu diketahui tingkat efektivitas pembelajarannya.

Pelaksanaan pembelajaran membaca puisi bertujuan agar siswa mampu membaca puisi. Materi membaca puisi akan diajarkan dengan menggunakan metode Pakem untuk menilai pengaruh terhadap pelaksanaan pembelajaran dan hasil pembelajarannya yang dilakukan pada siswa kelas VIII SMP Negeri 13 Langsa. Efektif tidaknya pelaksanaan pembelajaran dengan metode ini dapat diketahui dengan cara mengatakan suatu penelitian yang cermat dan sistematis. 


\section{METODE PENELITIAN}

Sesuai dengan masalah dan tujuan penelitian, maka penelitian ini menggunakan pendekatan kualitatif yaitu yang diutamakan pengungkapan makna dan proses. (Moleong, 2006) mengemukakan sebagai berikut: "Penelitian kualitatif memiliki ciri-ciri yaitu, berlatar belakang alamiah, karena sumber data langsung dari peristiwa, manusia sebagai alat, metode kualitatif analisis data cenderung bersifat induktif, teori dari dasar, bersifat deskriptif, lebih mementingkan proses, adanya batas, adanya kriteria khusus keabsahan data, desain yang bersifat sementara, hasil penelitian dirundingkan dan disepakati bersama."

Dalam pendekatan kualitatif analisis data dimulai sebelum peneliti berada dilapangan, selama peneliti berada di lapangan, dan setelah selesai di lapangan. Analisis telah dimulai sejak peneliti merumuskan dan menjelaskan masalah. Sebelum terjun kelapangan, dan berlangsung terus sampai peneliti menemukan hasil penelitian. Dalam hal ini. (Moleong, 2006) menyatakan "Analisis data adalah proses mencari dan menyusun secara sistematis data yang diperoleh dari hasil wawancara, catatan lapangan, dan dokumentasi." Data-data tersebut diorganisasikan ke dalam kategori, dijabarkan kedalam sub-sub masalah, melakukan sintesis, menyusunnya ke dalam pola, memilih data yang dianggap penting untuk dianalisis, dan ditarik simpulan.

Sehubungan dengan uraian di atas (Moleong, 2006) menyatakan "Metode-metode analisis data yang dapat dipergunakan adalah sebagai berikut ini. Mereduksi data yaitu proses yang meliputi kegiatan menyeleksi, memfokuskan, dan menyederhanakan semua data yang telah diperoleh, dari awal pengumpulan data sampai penyusunan laporan penelitian. Hasil tes dan hasil wawancara respon, pemahaman siswa serta data hasil observasi dimungkinkan masih belum dapat memberikan informasi.

Penyajian data yaitu pengorganisasian dari hasil reduksi data dengan cara menyusun sekumpulan informasi yang telah diperoleh dari hasil reduksi. Hal ini diharapkan dapat memberi kemungkinan menarik simpulan dan melakukan tindakan. Informasi yang dimaksud adalah uraian proses kegiatan pembelajaran, aktivitas Siswa terhadap kegiatan pembelajaran, dan hasil yang diperoleh sebagai akibat dari pemberian tindakan.

Penarikan simpulan, yaitu memberikan simpulan terhadap hasil penafsiran dan evaluasi, yang kegiatannya mencakup pencarian makna dan pemberian penjelasan. 
Selanjutnya dilakukan verifikasi, yaitu menguji kebenaran dan menyesuaikan maknamakna, yang timbul dari data.

Jenis penelitian yang dimaksud adalah penelitian tindakan kelas. Penelitian Tindakan Kelas (PTK) terdiri dari beberapa siklus. Setiap siklus terdiri atas (1) perencanaan (2) tindakan, (3) observasi, dan (4) refleksi. Penelitian ini dilaksanakan pada SMP Negeri 13 Langsa. Pemilihan lokasi ini didasarkan pada pertimbangan mutu dan aktivitas pembelajaran siswa perlu peningkatan lebih optimal dengan metode pakem. Selain itu, penelitian tindakan kelas ini pada lokasi tersebut dapat dilasaksanakan karena terletak di tengah kota dan tidak jauh jangkauannya dari peneliti. Dengan alamat jalan Prof. A. Madjid Ibrahim Gampong Matang Seulimeng, Kec. Langsa Barat, Kota Langsa.

Sumber data penelitian ini adalah siswa kelas VIII SMP Negeri 13 Langsa tahun pelajaran 2010/2011 yang berjumlah 4 kelas paralel. Penulis memilih kelas Kelas VIII/3 sebagai sumber data penelitian dengan jumlah siswa 35 orang. Metode pengumpulan data yang digunakan dalam penelitian ini adalah sebagai berikut: Tes awal (pre-tes) bertujuan untuk mengetahui keterampilan awal dalam membaca puisi. Tes akhir tindakan, bertujuan untuk mengetahui hasil pelaksanaan pembelajaran dengan menggunakan metode pakem. Tes akhir tindakan siklus pertama dan kedua dibandingkan untuk mengetahui ada tidaknya peningkatan keterampilan membaca puisi dengan metode pakem pada siswa kelas VIII SMP Negeri 13 Langsa.

\section{HASIL DAN PEMBAHASAN}

\section{Perencanaan}

Pada tahap perencanaan, kegiatan yang dilakukan adalah meliputi: 1) Memilih standar kompetensi, kompetensi dasar dan indikator pembelajaran; 2) Menyusun langkah-langkah pembelajaran dengan menggunakan penerapan pembelajaran kooperatif melalui metode pakem; 3) Menyusun lembar observasi atau lembar pengamatan aktivitas guru dan siswa sebagai alat untuk mengamati kondisi pembelajaran di kelas dalam pembacaan puisi ketika penerapan model pembelajaran metode pakem berlangsung; 4) Melengkapi alat bantu belajar untuk mengoptimalkan proses penelitian seperti LKS, format penilaian, instrumen penilaian, dan teks puisi. 


\section{Tindakan}

Sebelum model pembelajaran metode pakem diterapkan, terlebih dahulu penelitian memberikan pre-tes. Hal itu dilakukan untuk mengetahui kemampuan awal siswa dalam membaca puisi dan memberikan pengarahan bagaimana proses belajar mengajar metode pakem. Pelaksanaan KBM untuk setiap kali pertemuan mengikuti siklus rancangan Penelitian Tindakan Kelas (PTK) meliputi perencanaan, pelaksanaan, pengamatan, observasi, dan refleksi.

Pada siklus pertama, tahap perencanaan, peneliti menyusun rencana pelaksanaan pembelajaran (RPP-1) tentang materi pembelajaran membaca puisi. Di samping itu peneliti juga menyiapkan alat dan perangkat pembelajaran lainnya yang di perlukan dalam RPP-1. Setelah semuanya di persiapkan, peneliti menerapkan model pembelajaran metode pakem. Kemudian, peneliti membagi siswa dalam enam kelompok. kelompok I, 6 siswa, kelompok II, 6 siswa, kelompok III, 6 siswa, kelompok IV, 5 siswa, kelompok V, 6 siswa, dan kelompok VI, 6 siswa.

Peneliti memberikan tugas kepada semua kelompok. Kemudian, setiap kelompok membacakan puisi di depan kelas. Selanjutnya, kelompok lain menilai pembaca puisi tersebut menggunakan format penilaian yang telah di sediakan. Setiap siswa memikirkan dan mengerjakan tugas tersebut masing-masing dengan menggunakan format penilaian. Selanjutnya, siswa berpasangan dengan salah satu rekan dalam kelompok berdiskusi dengan pasangannya. Kemudian, pasangan bertemu kembali dalam kalompok berenam. Setiap kelompok mempunyai kesempatan menanggapi cara pembacaan puisi kelompok lain dengan menggunakan format penilaian yang telah mereka diskusikan bersama.

Selanjutnya, peneliti melakukan tindakan, yaitu melaksanakan kegiatan belajar mengajar (KBM) dengan menggunakan model pembelajaran metode pakem bedasarkan RPP-1yang telah di susun. Pada saat KBM berlangsung, penelitian melakukan pengamatan tehadap aktifitas guru dan siswa dengan berpedoman pada lembar observasi. Pengamatan dilakukan secara berkolaborasi dengan guru bidang studi bahasa dan sastra Indonesia di sekolah tersebut. Hal ini dilakukan agar semua tindakan guru dan siswa selama proses pembelajaran berlangsung dapat teramati. Kemudian peneliti melaksanakan kegiatan refleksi terhadap pelaksanaan RPP-1. Hasil refleksi dijadikan pedoman untuk merevisi berbagai kelemahan pada RPP-1 dalam menyusun RPP-2 kegiatan pembelajaran kedua. 
Berdasarkan hasil refleksi atau masukan pada kegiatan pembelajaran pertama, peneliti menyiapkan RPP-2 untuk silkus kedua dengan beberapa perubahan dari RPP-1 yang disesuaikan dengan hasil format penilaian. Selanjunya, peneliti melakukan tindakan yaitu melaksanakan KBM berdasarkan RPP-2.

Dalam melaksanakan KBM, peneliti melakukan pengamatan yang kedua terhadap aktivitas guru dan siswa selama proses pembelajaran metode pakem berlangsung. Pengamatan juga dilakukan secara berkolaborasi dengan guru bidang studi bahasa dan sastra Indonesia di sekolah tersebut. Hasil pre-tes pada pembelajaran dan hasil silkus 1 akan direfleksikan untuk mengetahui tingkat ketuntasan belajar. Dari perbandingan tersebut dapat ditarik kesimpulan kemampuan siswa dalam pembacaan puisi melalui model pembelajaran metode pakem.

\section{Observasi}

Langkah selanjutnya, peneliti membagikan puisi kepada setiap kelompok. Puisi tersebut berupa materi ajar, yaitu sebuah puisi dan beberapa pertanyaan di dalamnya. Setelah siswa membacakan puisi tersebut, mereka mendiskusikan di dalam kelompok masing-masing untuk mencari jawaban yang sesuai. Pada saat KBM berlangsung, peneliti melakukan pengamatan terhadap aktivitas guru dan siswa dengan berpedoman pada lembar observasi. Pengamatan dilakukan secara berkolaborasi dengan guru bidang studi bahasa dan sastra Indonesia di sekolah tersebut.

Selanjutnya, guru menerapkan metode pakem yang sesuai dengan langkah-langkah pada RPP-1 yaitu, menuliskan beberapa permasalahan yang terdapat di dalam materi ajar. Mengajukan beberapa pertayaan yang berhubungan dengan materi puisi. Pertanyaan tersebut dijawab oleh masing-masing kelompok yang ditunjuk oleh guru. Setelah semua jawaban telah di sampaikan oleh setiap kelompok, guru mendiskusikan secara bersama-sama untuk mencari jawaban yang tepat.

Langkah selanjutnya melakukan refleksi terhadap pelaksanaan RPP-1. Hasil refleksi dijadikan pedoman untuk merevisi berbagai kelemahan pada RPP-1 dalam menyusun RPP-2. Berdasarkan hasil refleksi atau masukan pada kegiatan pembelajaran pertama, peneliti mempersiapkan RPP-2 untuk siklus kedua. RPP-1 dan RPP-2 hampir sama namun perlu perubahan langkah-langkah yang kurang maksimal pada siklus pertama.

\footnotetext{
100 http://mahesainstitute.web.id/ojs2/index.php/jehss 
Selanjutnya, penulis melaksanaan KBM siklus kedua berdasarkan RPP-2 yang telah dipersiapkan

Pada saat guru melakukan KBM siklus kedua, pengamatan juga dilakukan dengan memberikan lembar observasi pada dua pengamat. Dari hasil kegiatan KBM kedua juga dilakukan tes akhir untuk melihat perbandingan peningkatan pemahaman siswa terhadap materi ajar. Dari hasil perbandingan tersebut ditarik suatu kesimpulan tentang kemampuan siswa membaca puisi dengan metode pakem pada siswa kelas VIII SMP Negeri 4 Langsa. Dalam siklus II ini peneliti juga mengamati segala prilaku siswa selama mengikuti pebelajaran.

\section{Refleksi}

Pada siklus II ini peneliti menganalisis hasil pengamatan terhadap kinerja siswa. Analisis kinerja ini meliputi sejauh mana siswa aktif dan antusias dalam mengikuti kegiatan memahami membaca puisi. Setelah menganalisis siklus II selesai, peneliti kemudian membandingkan hasil siklus I dengan siklus II. Dengan demikian permasalahan peningkatan kemampuan memahami membaca puisi dapat diketahui.

Lembar pengamatan aktivitas siswa dalam pembelajaran kemampuan siswa membaca puisi dengan metode pakem pada siswa kelas VIII SMP Negeri 4 Langsa. untuk mengetahui setiap aktivitas yang dilakukan siswa selama proses pembelajaran berlangsung.

Lembar pengamatan aktivitas siswa meliputi: aktif dalam kelompok, memperhatikan penjelasan guru, memahami tugas, mengerjakan tugas sesuai dengan permasalahan di LKS, memecahkan persoalan, menjawab persoalan yang diberikan oleh guru, dapat memberi saran di dalam kelompoknya, dan menjawab soal tes yang diberikan oleh guru.

Pengamatan dilakukan selama kegiatan belajar mengajar berlangsung dengan memberikan nilai 1, 2, 3, 4, dan 5 pada kolom skor dari deskriptor dengan kolom yang tersedia. Nilai 1 jika tidak terdapat deskriptor yang muncul, 2 jika satu deskriptor yang muncul, nilai 3 jika dua deskriptor yang muncul, nilai 4 jika tiga deskriptor yang muncul dan nilai 5 jika empat deskriptor yang muncul. Hasil keseluruhan skor di konversikan dengan rumus persentase, yaitu skor tertingi dibagi dengan skor terendah dikalikan seratus persen. Hasil persentase tersebut diterjemahkan dalam bentuk kualitatif, yaitu 
sangat baik, baik, cukup, kurang, dan sangat kurang (sesuai dengan tabel lembar observasi guru dan siswa).

Lembar pengamatan aktivitas guru dalam pembelajaran kemampuan siswa membaca puisi dengan metode pakem pada siswa kelas VIII SMP Negeri 4 Langsa, dilakukan untuk mengetahui setiap aktivitas yang dilakukan oleh guru selama proses pembelajaran berlangsung.

Lembar pengamatan ini meliputi: membentuk kelompok siswa, menjelaskan tujuan pembelajaran, membuat hubungan dengan kehidupan, menerapkan metode pakem, mengelola kelas, dan membuat penilaian. Pengamatan dilakukan selama KBM berlangsung yang dilakukan oleh guru pengamat. Sama halnya dengan lembar observasi siswa, lembar observasi guru juga memberikan penilaian pada kolom skor sesuai dengan kriteria yang telah ditetapkan. Nilai hasil pengamatan guru juga di lakukan analisis untuk dapat dijadikan pedoman dalam melihat tingkat keberhasilan pada siklus pertama.

\section{SIMPULAN}

Hasil penelitian pada materi membaca puisi yang diajarkan dengan menggunakan metode Pakem untuk menilai pengaruh terhadap pelaksanaan pembelajaran dan hasil pembelajarannya yang dilakukan pada siswa kelas VIII SMP Negeri 13 Langsa. menunjukkan bahwa (1) Perencanaan model Pakem, meliputi penyusunan Rencana Program Efektif, Program Semester, Silabus dan sistem penilaian, menyusun Rencana Program Pembelajaran, serta menyiapkan metode, media, alat bantu, bahan ajar dan penilaian; (2) Pelaksanaan model Pakem dilaksanakan dengan pemanfaatan lingkungan luar kelas untuk belajar karena prinsip belajarnya adalah belajar sambil bermain. Kegiatan pembelajaran diawali dengan salam pembuka, menulis indikator pembelajaran, mereview pelajaran sebelumnya dengan tanya jawab kemudian guru menerangkan inti dari materi yang akan diberikan selama beberapa menit saja setelah itu siswa yang aktif, guru hanya sebagai fasilitator, dan menutup pelajaran dengan refleksi bersama-sama dengan siswa; (3) faktor pendorong dan penghambat dalam penerapkan Pakem adalah: Pakem merupakan strategi pembelajaran yang memberikan kesempatan pada siswa untuk termotivasi dalam pembelajaran, sehingga memperoleh hasil yang baik. Dengan model Pakem, dapat mengurangi situasi dan kondisi model pembelajaran konvensional yang lebih menitik beratkan pada metode ceramah. Sedangkan faktor penghambatnya 
adalah: Belum dipahaminya model Pakem oleh guru. Kurangnya memperoleh kesempatan memahami inovasi dalam pendidikan, termasuk penerapan model Pakem. Kecenderungan diterapkannya model pembelajaran konvensional yang dipandang lebih mudah dan murah, dan karena kemampuan tingkat berfikir siswa yang beragam, jadi guru masih belum optimal dalam menerapkan Pakem.

\section{DAFTAR PUSTAKA}

Agriawan. (2001). Belajar yang Menyenangkan Sebuah Prosedur. Gema Media. Jakarta.

Agus, M. (2001). Pendekatan Belajar Aktif. Angkasa: Bandung

Ali, M, (1988). Konsep dan Penerapan CBSA dalam Pengajaran. Bandung: P.T. Sarana Panca Karya.

Arikunto, S. (2009). Pengololaan Kelas dan Siswa Sebuah Pendekatan Evaluatif, Jakarta: Rajawali Pers.

Bugin, M. (2008). Penelitian Kualitatif di unduh di htbp;//educatioan. Jlab. Org/radngninglwater. Cicle 01.gif.

Daiches. (2000). Macam-Macam Puisi di unduh di http;//educatioan. Jlab. Org/radingAing/ water. Cicle 01.gif.

Depdiknas. (2006). Kurikulum K-13 SMP/MTs. Jakarta: Ditjen Dikdas.

Depdiknas. (2008). Pembelajaran Dengan Metode Pakem. Jakarta: Diden Diknas.

Hendriani, Y, (2007). Model Pembelajaran PAKEM. SD Bandung: PPPG.

Iqbal, M.A. (2002). Inovasi Pembelajaran . Jakarta; Pustaka Karya

Maleong, L. J. (2006). Metodologi Penelitian Kualitatif. Bandung: Rosdakarya.

Mulyani, A.N. (1981). Pembinaan Minat Baca dan Promosi Perpustakaan. Berita Perpustakaan Sekolah, I, $24-29$.

Nurhadi. (1987). Membaca Cepat dan Efektif. Bandung: Sinar Baru dan Malang: YA3 Malang.

Pertiwi, A.W.E. Madinah, F.Z. \& Wulandari, R. (2017). Estetika Antologi Puisi-Puisi Pujangga Baru. Gondang: Jurnal Seni dan Budaya, 2 (1): 9-19.

Rusyanto, H .(2001). Cara Belajar Menyenangkan. Jakarta: Depdikbud.

Semiawan, C, dkk. (1987). Pendekatan Keterampilan Proses. Jakarta: Gramedia

Situmorang, B.P. (1983). Puisi. Teori Apresiasi Bentuk dan Struktur. Ende-Flores:Nusa Indah.

Sudjana, N. (1987). Cara Belajar Siswa Aktif dalam Proses Belajar Mengajar. Bandung: Sinar Baru

Suharianto. (2000). Pengantar Apresiasi Puisi. Surakarta: Widya Duta.

Suparlan, D, \& Danny. (2008). PAKEM (Pembelajaran Aktif, Kreatif, Efektif dan Menyenangkan). Bandung : PT Genesindo

Suprihatin. (2001). Belajar yang Efektif. Analisa: Jogjakarta.

Syah, M. \& Kariadinata, R. (2009) Pembelajaran Aktif, Inovatif, Kreatif, Efektif dan Menyenangkan (PAIKEM). Pendidikan dan Latihan Profesi Guru (PLPG) Rayon Fakultas Tarbiyah dan Keguruan UIN Sunan Gunung Djati Bandung.

Tim MBS Unesco-Unicef. 2003. Menciptakan Masyarakat Peduli Pendidikan (Paket Pelatihan ). Jakarta: Perwakilan Unesco -Unicef.

Waluyo, H.J. (1998). Teori dan Apresiasi Puisi. Jakarta: Erlangga 